\section{Wildfires in Algeria: problems and challenges}

\author{
Ouahiba Meddour-Sahar
}

In the scenario of the Mediterranean area, where about 54000 fires and 0.4 million hectares of forest are burned and annually registered (2006-2010), the rank for Algeria is non-negligible with 4.11 million hectares of forest. The annual number of fires and the size of area burned depict a critical situation, which became rather dramatic in 2012. Climate change projections and the estimated changes to wildfire risk for the future decades (2030-2060) indicate that the entire Maghreb region, including Algeria, will be among the most affected areas of the Mediterranean. Longer fire seasons will be experienced and extended by an additional month with each passing year. Despite Algeria's recent investments in technical means for controlling forest fires, the current suppression-oriented model seems unable to cope with such a phenomenon. Furthermore, the model is unfit in view of the approaching scenario, when fire-exclusion policies need to be complemented with fuel-reduction techniques and fire prevention management. This study aims to establish an understanding of the context and public policy issues related to wildfire management in Algeria. Data were collected by distributing questionnaires to foresters with the objective of identifying obstacles and constraints hindering the efficacy of pro-active measures. Analysis of the data gathered indicates that Algerian foresters are well aware of the importance of prevention, contrasting with current governmental policies that are predominantly oriented towards improving the technical extinction apparatus. A SWOT analysis suggests possible strategic options for improving the efficiency of wildfire control by building on strengths, eliminating weaknesses, exploiting opportunities, and mitigating threats. The results of this study may be adapted to other countries with similar problems as those of Algeria.

Keywords: Algeria, Forest Fires, MENA, Prevention Policy, SWOT Analysis

\section{Introduction}

In the period 2003-2010, more than 5 million ha of forest were burned in the Mediterranean region, and more than 600000 wildfires were registered (FAO 2013). From 2006 to 2010 , approximately 269000 fires burned a total of 1907512 ha of Mediterranean forests, other wooded lands (OWLs), such as shrubland and grasslands (on average 54000 fires and 0.4 million ha per year, respectively), and agricultural lands (FAO 2013); of the total area burnt (38\%), about 731000 ha were forests. Approximately $78 \%$ of these fires burned in four southern countries of the EU (Greece, Italy, Portugal, Spain), and 50\% only in Portugal and Spain.

In the future climate change prediction scenarios, wildfire risk is forecast to increase nearly everywhere in the Mediterranean region (Giannakopoulos et al. 2009), with the southern Mediterranean area being at higher risk all year round. Projections for 2030 to 2060 suggest that the Maghreb (and the Balkans, North Adriatic, Central Spain, and Turkey) will suffer at least an additional month of high wildfire risk (Giannakopoulos et al. 2009).

Whereas the five southern member states of the EU (or Western Mediterranean countries - FAO 2013), the so-called fire club (Vélez 2000), are well considered within the fire literature, the same cannot be said for the sou-

$\square$ Department of Agricultural Sciences, University Mouloud Mammeri, Box 17 RP, 15000 Tizi Ouzou (Algeria)

@ Ouahiba Meddour-Sahar (o.sahar@yahoo.fr)

Received: Mar 04, 2014 - Accepted: Dec 10, 2014

Citation: Meddour-Sahar 0, 2015. Wildfires in Algeria: problems and challenges. iForest 8: 818-826 [online 2015-03-25] URL: http://www.sisef.it/iforest/contents/?id=ifor1279-007

Communicated by: Davide Ascoli thern Mediterranean Maghreb countries. For instance, it was only in 2010 that the European Forest Fire Information System (EFFIS) started to include Northern African countries in the mapping of burnt areas and the assessment of fire danger (European Commission 2013). The wildfire problems experienced in some Middle East and North African (MENA) countries, such as Algeria, are therefore almost unknown despite the fact that they significantly contribute to general wildfire statistics within the Mediterranean Basin area (Meddour-Sahar et al. 2013a). In the period from 2006 to 2010, for example, the total number of fires recorded in Algeria was 12230 compared with 6996 in Greece. The total burnt area in Algeria during the same period was 147685 ha, representing about $8 \%$ of the total burnt area in Mediterranean countries (including forests, OWLs, and agricultural lands); this percentage was greater than for Bulgaria (3\%), Turkey $(3 \%)$ and France $(3 \%$ - FAO 2013).

Fire management challenges are not currently an object of great interest in North Africa, where recent literature on wildfires is rather scarce and mainly oriented towards fire ecology studies (Madoui et al. 2006, Ouelmouhoub \& Benhouhou 2007, Bekdouche et al. 2011, Slimani et al. 2014) or remote sensing analysis (Khader et al. 2009, Guettouche et al. 2011, Haddouche et al. 2011). In the Western Mediterranean region, a number of researchers have approached the challenges of fire management by exploiting the knowledge of experts: with local farmers and fire experts in Spain (Zarraga Moreno 1988, Marino et al. 2014, Raftoyannis et al. 2014); in the analysis of training provided to Portuguese forestry workers and their opinions on fires (Colaço 2005, Colaço et al. 2005, 2006); regarding the prevention of unwanted fires (Boström et al. 2013); regarding agro-forestry farmers/landowners' attitudes towards fire prevention, including their perceptions of the causes of fires (Xavier \& De Belém Martins 2010); and in the evaluation of the reduction of forest fire risk in Catalonia (Mogas \& Riera 2001). A number of other projects have adopted similar approaches, such as FireSmart (Sebastián-López et al. 2011) and FireParadox (Silva et al. 2010a). Moreover, the Community-Based Fire Management (CBFiM) approach to fire management (FAO 2011) adopts similar tools, such as the Participatory Rapid Appraisal, to identify the strengths and weaknesses of projects. We consider expert analyses to be a potential and practical tool for developing a deeper understanding of fire management issues in Algeria, which provides a highly useful and relevant case study for exploring some of the challenges related to wildfires (i.e., fires are a permanent threat 
within the country and little research has been conducted by fire science researchers). In addition, the results of this study will be of significant interest to other countries with similar socio-economic conditions.

In recent years, Algeria has invested in fire suppression activities. However, until now no national assessment has been conducted on the wildfire control apparatus within the country. Our interest stems from the need to examine the current organization and to develop strategic recommendations for overcoming possible obstacles and limitations. Hence, the purpose of this study is to survey and evaluate the national wildfire control service in Algeria, establishing an understanding of the context and public policy issues related to wildfire management, with the objective of identifying obstacles and constraints hindering the efficacy of pro-active measures. Research was conducted using the criteria of the FireSmart project (EU $7^{\text {th }}$ Framework Programme 2007-2013 concerning forest fire preventive measures) with the collaboration of the Algerian Forest Administration (General Directorate of Forests, DGF), which permitted and provided direct, personal contact with foresters. Thus, the opportunity was given to evaluate the results with those already obtained in Southern $\mathrm{Eu}$ rope (Silva et al. 2010b, Marino et al. 2014).

\section{Methods}

\section{Study area: history, wildfire policies and current control apparatus}

In the wildfire scenario of the Mediterranean area, the rank for Algeria is non-negligible with 4.11 million ha of forest $58 \%$ of which is degraded bush; forestry ratio $1.76 \%$ ). The paucity of forests and the growing threat of desertification render fires particularly devastating. Despite huge investments in the national fire control apparatus, the yearly number of wildfires is increasing. From 1876 to 2012 , the cumulative surface burned in Algeria was 5272717 ha, which is close to the forested area of about 5 million ha in 1830 before the French colonization (Megrerouche 2006). During certain seasons, the number of burned surfaces surpassed 200000 ha, as in 1956, 1983 and 1994 (204 220, 221367 and 271598 ha, respectively). More recently (1985 to 2010), 1636 fires were annually recorded and on average 35024 ha of forest were burned (Meddour-Sahar 2014). The current forest fire fighting policy is based on suppression and prevention; the latter mainly relying on the colonial model (De Ribbe 1869) of fire prevention grounded on infrastructures that are not distributed across the territory according to risk level but rather according to administrative and local political criteria (Meddour-Sahar 2014). The main actors of fire policy in Algeria are the Civil Protection organizations (Ministry of the Interior and Local Governments) and the Forest Service (Ministry of Agriculture and Rural Development). A plethora of other stakeholders are also involved. This results in the existence of multiple decision-making centers, which are ineffective and inefficient. Wildfire protection programs are implemented by the Forestry Service (2229 individuals organized within 456 Forest Mobile Patrols for initial attacks and 922 units staffing 375 fire lookout towers). In addition, there are 6000 Civil Protection units and 42088 seasonal forest workers. The program also relies on $404 \mathrm{WD}$ Medium Tankers, 800 firefighting trucks, 1617 water points, 32556 ha of firebreaks, and $37933 \mathrm{~km}$ of forest roads and fire trails (Meddour-Sahar et al. 2013b).

\section{Structured questioning}

Research was conducted through a quantitative survey administered to technicians working in the DGF who are involved in forest fire control field operations. Structured questioning was achieved through the use of an ad hoc questionnaire borrowed from the FireSmart questionnaire (Sebastián-López et al. 2011). The questionnaire included 62 questions structured into five groups of closed-ended questions, with a predetermined set of potential responses (professional activity; forest fire management; forest fire prevention; infrastructures; conflicts influencing fire prevention), and an open-ended question. Responses to the questions were classified using scores from 1 to 10 , or the Likert scale (Likert 1932). Other scales were also used, mirroring the same technique used within the FireSmart questionnaire. When the scale of 1 to 10 was used, results were expressed in terms of mean \pm standard deviation (SD).

\section{Panel of experts}

The DGF provided the names of all foresters operating within the 40 wilayas (provinces) of northern Algeria that experience wildfire problems. These foresters are involved in forest fire control and therefore considered to be very knowledgeable. From this list we randomly selected 10 people per wilaya, for a total of 400 individuals, to serve as our panel of experts. The questionnaire was mailed to each member of the panel.

\section{SWOT Analysis}

The questionnaire results were synthesized using a SWOT (Strengths, Weaknesses, Opportunities and Threats) analysis. The Strengths and Weaknesses are internal, controllable factors, which can be acted upon; they exist now and refer to the current situation. The Opportunities and Threats are external, independent and uncontrollable factors (Ghiculescu et al. 2011); they refer to events that might happen in the future or are waiting to happen (Suh \& Emtage 2005). SWOT analysis is a common tool used for analyzing a project, program, activity, etc. (Suh \& Emtage 2005, Lu 2010, Ghazinoory et al. 2011), and for obtaining support for strategic planning and decision-making (Marino et al. 2014). SWOT analysis is often used within the forest sector (Blinn et al. 2007, Rauch 2007, FAO/JRC/CFS 2008, Gerasimov \& Karjalainen 2008, Plana 2010, Marino et al. 2014). However, to our knowledge, the present study is the first to apply this technique to forestry issues in Algeria and at MENA country level.

\section{Results and discussion}

\section{Participants' background information}

From the 400 foresters contacted by e-mail at the national level, we received 228 replies, representing a response rate of $57 \%$. The responses were irregularly distributed per $w i$ laya. A sample profile in terms of age, gender, level of education, type of employment, and working region was recognized as a factor influencing perception/opinion of respondents (Williamson et al. 2005, Colombo 2006, Raftoyannis et al. 2014). Our sample $(\mathrm{N}=228)$ is mainly composed of males $(\mathrm{n}=$ $221,97 \%)$. The presence of females $(n=7)$ is concentrated in the 31- to 41-year agegroup. The dominant age-groups were 41 to 51 years (122 individuals, $54 \%$ of the total, followed by the $51+$ age-group (54 individuals, $24 \%$ of the total). The sample was therefore composed of mostly aged people (176 individuals, 3 females), representing $77 \%$ of the total; the average age of the interviewees was 46 years. "Experience" was divided into four age-groups $(<11,11-21$, 21-31 and $31+$ years) yielding the following values: 11 to 21 years $(26 \%)$ and 21 to 31 years $(52 \%)$. In conclusion, $78 \%$ of the respondents have an experience at more than 11 years of age. All grades, with 7 classes, were contacted, 3 of which were represented by officer classes (Conservateur, Inspecteur Divisionnaire, Inspecteur subdivisionnaire) accounting for $48 \%$ of the respondents. All respondents with the officer's grade have a university level education (Degree in Forestry Engineering).

Chi-squared test statistics of dependency between age, experience and all items in the questionnaire were carried out by Sphinx survey and statistics software package (http://www.sphinxsurvey.com/). Dependency between age, experience, and the responses to the questionnaire that were calculated as significant are reported in Tab. 1.

As expected, the driving factors were age and experience. Although we obtained the most important results, not too much emphasis was ascribed to personal influence, considering that all contacted individuals work 
within the DGF (a homogeneous technical and administrative unit with a strong hierarchy and well-defined set of customs, norms, and standards and in which all components share common rules, values and objectives). In short, we considered the DGF as a unit in which interpersonal differences were not so crucial.

\section{Forest fire management}

Results are presented in terms of average rating or percentage of respondents agreeing or disagreeing with the statements. Appendix 1.1 presents the results of the questions relating to management and response. The responses were scored on a scale from 1 to 10 points, with 10 being the highest score; the scores were expressed as mean $\pm \mathrm{SD}$ and were rather scattered. High scores $(8$ points and over) were only attributed to the importance of the forest and to the ecological and environmental impact of fires. Medium scores (6 to 8 points) were attributed to a number of issues, with the importance of prevention receiving the highest score (7.56 \pm 2.38 ). Other issues receiving a medium score were training of personnel, the investigation of causes of fire, campaigns and public awareness, the importance of politics, and the effects of fuel management. The question of whether wildfires are important from a socio-economic point of view received a rather moderate score $(6.57 \pm 3.14)$. Relatively low scores (less than 6 points) were attributed to technical factors hindering fire prevention, scarce perception of fire by the public, conflicts of interest among different social agents, coordination among different agents intervening in fire control, and economic factors. The lowest score $(4.40 \pm 2.93)$ was recorded for the question if legal factors were limiting the success of forest fire prevention activities.

\section{Forest fire prevention}

Appendix 1.2 presents the experts' responses in relation to fire prevention activities. The responses were classified using a five-point Likert scale. The results were commented by the sums of percentages of 1 and 2 (Strongly disagree and Disagree) and 4 and 5 (Agree and Strongly agree), without considering the neutral opinion of undecided respondents, which reached a maximum of $25.76 \%$ and a minimum of $1.75 \%$ of responses. "Prevention" $(93.89 \%$ as the sum of Agree and Strongly agree) was perceived as a more efficacious strategy than extinction of forest fires. We emphasize this high value because "an empirical generalization or communication is deemed objectively true or confirmed if there is a broad consensus on this subject by a group of experts" (Mitroff $\&$ Turoff 1975). This finding aligns Algerian foresters to those of other countries, where prevention is considered the priority appro-

Tab. 1 - Chi-squared test statistics of dependency between age, experience, and responses to the questionnaire. (df): degrees of freedom.

\begin{tabular}{lrrc}
\hline Dependency & $\boldsymbol{\chi}^{\mathbf{2}}$ & df & 1-p (\%) \\
\hline Age/Experience & 194.82 & 9 & 99.99 \\
Age/Grade & 54.87 & 18 & 99.99 \\
Age/Wilaya & 124.76 & 78 & 99.94 \\
Age/Budget (financial contribution to prevention) & 23.43 & 12 & 97.57 \\
Age/Training & 26.33 & 12 & 99.04 \\
Age/Detection & 53.45 & 27 & 99.82 \\
Age/Cleaning, thinning and pruning of forests & 45.50 & 27 & 98.56 \\
Experience/Grade & 59.96 & 18 & 99.99 \\
Experience/Wilaya & 103.48 & 78 & 97.16 \\
Experience/Detection & 44.15 & 27 & 98.01 \\
\hline
\end{tabular}

ach (Molina et al. 2010, Montiel \& Herrero 2010, Sebastián-López et al. 2011, EFIMED 2012, Marino et al. 2014)

We defined an index of agreement $\left(I_{\mathrm{ag}}\right)$ according to the following formula (eqn. 1):

\section{$I_{a g}=\frac{\%(\text { Agree }+ \text { Strongly agree })}{\%(\text { Strongly disagree }+ \text { Disagree }+ \text { Undecided })}$}

i.e., from the percentages in columns $(4+5) /$ $(1+2+3)$ in the Appendix 1.2. The higher the ratio, the stronger the level of agreement. A strong level of agreement $\left(I_{\mathrm{ag}}\right)$ was found for the following statements (the ratio is shown in brackets): "forest fire prevention is more effective than extinction" $\left(I_{\mathrm{ag}}=16.53\right)$, which received the highest agreement level; "public awareness directed at the rural population reduces the forest fire problem" $\left(I_{\text {ag }}=12.42\right)$; and "it is necessary to provide legislation and specific recommendations for fire prevention within the wildland-urban interface" (WUI $-I_{\mathrm{ag}}=10.40$ ).

We found a more modest $I_{\text {ag }}$ for the following statements: "suitable planning of land uses benefits forest fire prevention" $\left(I_{\mathrm{ag}}=\right.$ 4.85) and "an increase in financial expenditure on prevention multiplies its effectiveness" $\left(I_{\text {ag }}=4.70\right)$. Finally, the lowest $I_{\text {ag }}$ was recorded for the following statements: "public forests are properly managed for forest fire prevention" $\left(I_{\mathrm{ag}}=0.62\right)$ and "private forests are properly managed for forest fire prevention" $\left(I_{\mathrm{ag}}=0.21\right)$. These results confirm the need to focus further on wildfire prevention (Marino et al. 2014).

\section{Infrastructures}

Responses (Appendix 1.3) are characterized by relatively high SDs, indicating a wider dispersion of respondents' points of view. Traditional infrastructures (forest roads and fire trail networks, fuel breaks, lookout towers and water supply points) as well as monitoring and detection were highly rated, scoring more than $8 / 10(8.60 \pm 2.08$ and $8.16 \pm 2.67$, respectively). Forestry operations as well as opening and maintenance of fuel breaks $(8.03 \pm 2.41)$ and cleaning, thinning and pruning $(8.60 \pm 2.08)$ were well appreciated by the foresters. Meteorological forecasting systems $(7.12 \pm 2.8)$ and fire risk and hazard prediction $(6.81 \pm 2.68)$ were also rated highly. On the contrary, fuel management and techniques (Lovreglio et al. 2014, Torres-Manso et al. 2014) such as controlled grazing $(6.06 \pm 3.04)$ and prescribed burning $(4.86 \pm 3.11)$, which are new for Algeria and not known by personnel, were rather poorly rated. A similarly low rating was given to restrictions on public activities $(6.00 \pm 2.74)$.

\section{Conflicts}

Using a scale from 1 to 4 , respondents were asked to rate to what degree conflicts hinder the management and prevention of forest fires, with 1 and 2 expressing a low degree and 3 and 4 a high degree. Conflicts could be classified (Appendix 1.4): between groups of actors (e.g., urban and rural populations), but also within the same socio-professional group (e.g., among residents), and between people and the State, the latter represented by the foresters. In this case, conflicts are probably related to areas such as forests and parks where the interests of local residents and the State diverge. The main conflicts occur between livestock and forest owners, followed by conflicts between residents in the WUI and the public administration. The results confirm the findings by other authors (Taylor 1997, Sebastián-López et al. 2011) and are evidently related to the presence of conflicting forms of land use.

\section{Open-ended questions}

Responses provided to the open-ended questions can be grouped within the following categories: awareness; finance; firefighting organization; legislative measures; policy; population; prevention; silvicultural measures; and training and recruitment. Because responses are rather difficult to synthesize, we translated their text from French or Arab into English and created a word cloud where the importance of each term is directly related with their font size. The results of this representation are shown in Fig. 1.

"Prevention" was identified as the most frequent and important word. This result in- 


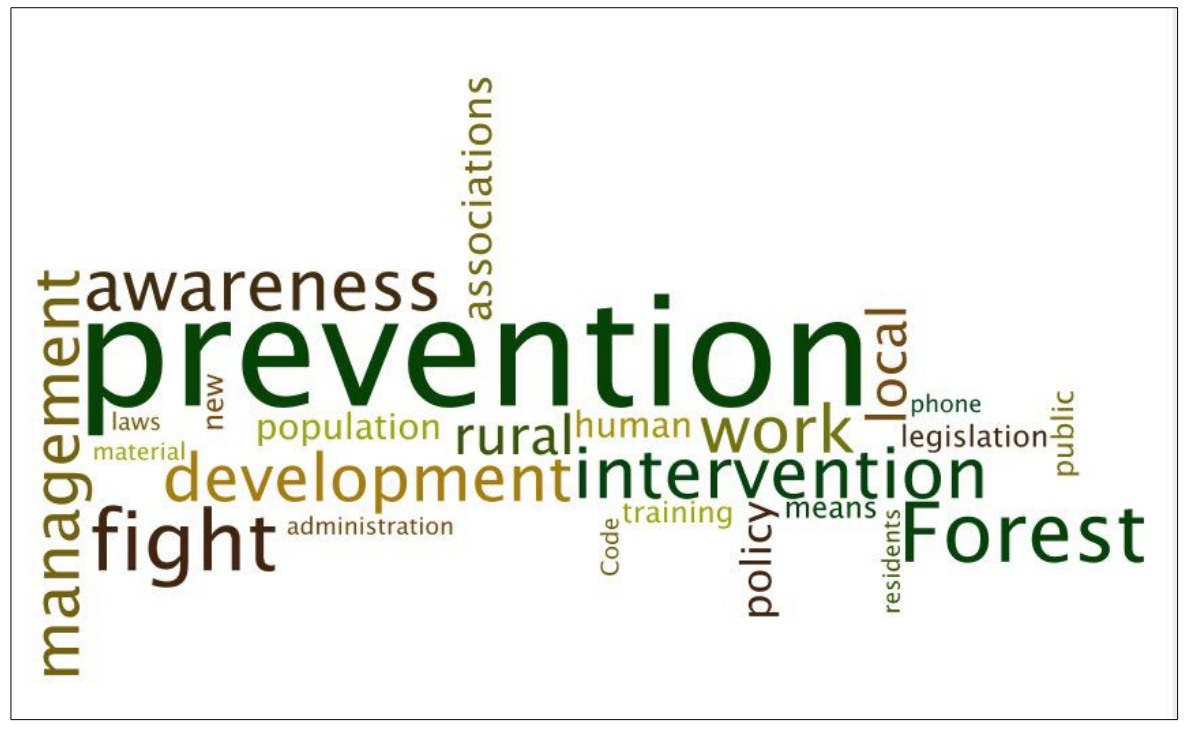

Fig. 1 - The cloud of most frequently cited words (50 words).

dicates that foresters in Algeria are well aware of the relative importance of prevention contrasting with current governmental policies, which are mainly oriented towards improving the technical extinction apparatus.

\section{SWOT matrix of forest fire management in Algeria}

SWOT analysis permits the formulation of suggestions to improve prevention and control strategies. For its implementation, results from the survey and other research (Meddour-Sahar 2014) were utilized. Such analysis identified the most important internal and external factors and, consequently, derived strategies. A list is presented in Tab. 2 , which includes only the more prominent items of SWOT components, each of which is identified by the capital letter of the component and a progressive number (e.g., S1, S2, etc.).

The qualitative assessment identified 5 factors of strengths (S), 17 of weaknesses (W), 13 of opportunities (O) and 10 of threats (T). Weaknesses were the most significant determinant, with an overall importance of about $38 \%$.

\section{SWOT strategy formulation}

A SWOT matrix conceptually indicates distinct alternative strategies, based on the interactions of different variables. Four sets of strategies can be formulated by pairing each of the internal factors with each of the external ones, namely: (i) SO (maxi-maxi strategies): internal strength(s) realize the available external opportunities (ideal case); (ii) ST (maxi-mini strategies): internal strength(s) minimize the potential impact of external threats; (iii) WO (mini-maxi strategies): reduce internal weakness(es) or develop missing strength(s) to realize external opportunities; and (iv) WT strategies (mini- mini strategies): reduce internal weakness (es) and avoid or minimize external threats (defensive strategy, worst case scenario Weihrich 1982, Rauch 2007, Ghazinoory et al. 2011, Mohamad et al. 2012, Ohadi et al. 2013).

\section{Evaluation of possible strategic options}

The final step of our SWOT analysis was to suggest possible options for improving the efficiency of the wildfire control apparatus in Algeria. Combinations of SWOT factors yielded comprehensible results (e.g., W1, O3 means that Weakness 1 and Opportunity 3 have been considered).

\section{WO and WT strategies}

- Given the increased frequency of large fires it is mandatory to adopt modern fightand aerial means, and to improve the infrastructure network to ameliorate access to forests $(\mathrm{W} 1, \mathrm{O} 3)$. It is also important to avoid the loss of traditional knowledge in the use of fire (TFU, traditional fire use) as a management tool (W1, T3) by incorporating people from the countryside (experts in TFU) into firefighting crews.

- An impressive network of infrastructures (firebreaks, water supply points, forest roads and fire trails) has been realized in Algeria, but it lacks the necessary and timely periodical maintenance, which alone can assure continued efficiency.

- It is mandatory to maintain infrastructures (W5, O3) also by exploiting the traditional knowledge of fire use (W5, T3) and using controlled grazing (W5, O12; W5, T6). These measures need to be accompanied by a better use of fire as a smart prevention tool (W3, O6) under the form of prescribed burning, which should be gradually introduced (W5, T3) and accompanied by aping techniques, such as suppression fires propriate training of personnel.

- Resolving the irregularity of funding is a priority for improving prevention in order to eliminate poor maintenance of prevention infrastructures (W5, W8, O3).

- An increase in the number of fires within WUIs is not accompanied by an adequate awareness of risk by inhabitants. Possible mitigation measures are information campaigns targeted at WUI inhabitants (W2, $\mathrm{O} 2, \mathrm{O} 10, \mathrm{O} 11)$ and the inclusion of fire smart WUI management in urban plans for fire prevention (W3, O2).

- The careless or illegal burning of straw and other residues, but mainly the dumping and subsequent burning of garbage in or near forests is among the most frequent causes of wildfire ignition (Meddour-Sahar et al. 2013c). A different and wiser use of burning under legal regulations should therefore be disciplined by the new Forestry Code (W4, T3 and W4, O8).

- Preventive silvicultural measures, such as thinning, pruning, and local shrub clearings, are efficacious but costly; incentives and obligations (W6, O3) should therefore be introduced within the Forestry Code (W6, O8) and public forest management plans (W6, O4).

- Preventive silvicultural measures as above must also be promoted to foster the resistance and resilience of forest areas, if affected by fire (W8, O1).

- Privately owned forests must be clearly identified by the Cadastre (W6, O9), and owners should benefit from an appropriate regime of incentives. This could create job opportunities for local residents (W6, O1) and help to reduce the popular belief that the forest is nobody's land (W6, T2). When people have formal and legally recognized ownership of resources and can see long-term benefits from their land management, they will tend to be more concerned with the protection and sustainable management of those resources (FAO 2011).

- The national policy for wildfire control gives excessive emphasis to fire extinction at the detriment of fire prevention (W7, O3), since suppression-oriented actions seem to prevail (W7, T1). Future scenarios of higher risk, intensity and frequency of wildfires (W7, T7) confirm the restriction of suppressive actions and the opportunity presented by not limiting policy choices to suppression efforts but by investing more in fire management and prevention.

- The inadequate distribution of personnel among and within the different wilaya does not align with the risk criteria, and the number of personnel is substantially low if related to forest extension. We suggest an increase (W8, W9, W10, O5) in budget levels and DGF staff (W9, O3), with personnel distribution focused in priority areas identified by fire risk maps 
Tab. 2 - Relevant factors identified in each SWOT category.

\begin{tabular}{|c|c|}
\hline Strengths & Weaknesses \\
\hline S1. Algeria has specific policies and laws for wildfire fighting & W1. Increasing frequency of large fires \\
\hline S2. Importance of forest sector in local job creation & W2. Insufficient awareness of residents living in WUI areas \\
\hline $\begin{array}{l}\text { S3. Important fire fighting apparatus mainly based on infrastruc- } \\
\text { tures (e.g., firebreaks, water points, lookout towers, forest roads } \\
\text { and fire trails) }\end{array}$ & $\begin{array}{l}\text { W3. Increase in fire number within WUI areas } \\
\text { W4. Increased number of fires caused by the careless burning of stubble, } \\
\text { weeds and garbage }\end{array}$ \\
\hline \multirow{13}{*}{$\begin{array}{l}\text { S4. Reforestation program of } 1245900 \text { ha with an investment ef- } \\
\text { fort of U.S.\$ } 133 \text { million } \\
\text { S5. Projects of Rural Development (PPDR) for job creation }\end{array}$} & W5. Insufficient maintenance of infrastructures \\
\hline & W6. Inadequate regulations governing preventive measures \\
\hline & W7. Protection against wildfires limited to fighting activities \\
\hline & W8. Lack of funding for fire prevention through silvicultural measures \\
\hline & W9. The distribution of personnel not meeting the risk criteria \\
\hline & W10. Lack of personnel in relation to the country's forest extension \\
\hline & W11. Multiplicity of actors in fighting apparatus \\
\hline & $\begin{array}{l}\text { W12. Lack of adequate penalties against culprits in general forest legis- } \\
\text { lation }\end{array}$ \\
\hline & W13. Spontaneous and limited scope of awareness programs \\
\hline & W14. Lack of weather stations \\
\hline & W15. Non-involvement of citizens when faced with a fire \\
\hline & W16. Lack of adequate training of personnel \\
\hline & W17. Inadequate knowledge of high risk areas \\
\hline Opportunities & Threats \\
\hline O1. Creation of more jobs and income for local residents & T1. Suppression-oriented actions more important than prevention \\
\hline O2. Dedicated legislation for the WUI areas & $\mathrm{T} 2$. Forest belonging to no one in the mind of the average citizen \\
\hline \multirow[t]{2}{*}{$\begin{array}{l}\text { O3. Increasing the extinction efficiency ensuring a fast attack; im- } \\
\text { provement of auxiliary tools (maps, GPS, etc.) }\end{array}$} & T3. Loss of traditions in the knowledgeable use of fire \\
\hline & T4. Increasing arson where the land is of great value \\
\hline O4. Management plans for all state forests & T5. Land use changes cause an increasing number of fires \\
\hline \multirow{2}{*}{$\begin{array}{l}\text { O5. Increase the number and improve allocation of human re- } \\
\text { sources; permanent training of technical staff }\end{array}$} & T6. Overgrazing in forests \\
\hline & T7. Climate change and thus expected risk that the phenomenon could \\
\hline O6. Use expert tactics and preventive fire in forest management & worsen \\
\hline O7. Severe fire police & T8. Rural exodus and suburbanization \\
\hline O8. Approval of the new Forestry Code & T9. Low level of interaction between researchers and managers \\
\hline $\begin{array}{l}\text { O9. Finalization of the forest registry to update the ownership of } \\
\text { forests }\end{array}$ & T10. Forest management not given high priority on the political agenda \\
\hline \multicolumn{2}{|l|}{ O10. Information and awareness campaigns } \\
\hline \multicolumn{2}{|l|}{$\begin{array}{l}\text { O11. Increase citizens' awareness about consequences and social } \\
\text { costs of fires }\end{array}$} \\
\hline \multicolumn{2}{|l|}{ O12. Introduce controlled grazing } \\
\hline O13. Scientific and technical know-how on wildfire control & \\
\hline
\end{tabular}

(W14, O5). This could also lead to more job and income opportunities for local residents (W9, O1).

- A plethora of stakeholders are currently involved within the wildfire fighting apparatus. This results in an inefficient multiplication of decision centers, at the detriment of extinction efficiency (W11, O3), and calls for a reduction of stakeholders and a well-defined chain of command and control.

- Lack of adequate penalties against culprits in current forest legislation and extremely low fines have no deterrent effect, but rather represent a challenge for repeat of fenders to ostentatiously break the law. A review and update of the monetary revaluation of fines and a reformulation of the penal system for voluntary fire setting should be introduced within the new Forestry Code together with more severe actions on the part of fire police (W12, O7,
O8).

- Authorities must be given the tools to reduce arson where forested land is of great value due to urban sprawl, a situation that is being caused by rural exodus and suburbanization (W12, T4, T8).

- Authorities must be given the tools to contain the increasing number of deliberate fires caused by illegal land use changes (W3, T5), which are not currently prosecuted.

- Awareness campaigns appear rather generalist, abstract and not oriented to change the negligent behavior of specific social groups. It seems mandatory to invest in awareness campaigns that are clearly targeted (W13, O10), professionally projected and inspired by so-called social communication.

- Campaigns must increase citizens' awareness of the impacts of fires and the consequences and social costs of fires (W13,
O11), as well as the high cost of post-fire relief and recovery.

- Campaigns should influence public understanding and change citizens' largely indifferent attitude to wildfires (W15, O11). For example, campaigns should encourage more collaboration from the public. A more active participation in firefighting operations from the public is sometimes inadvisable, since it could imply important operational problems mainly related to safety. Promoting associations of properly trained volunteers is an option that is showing good results in several countries.

- Weather stations are currently irregularly distributed, and their main objective is to collect data for agricultural purposes. It seems necessary to install a network of automatic weather stations within forested areas to facilitate the calculation of fire danger and risk indexes, which could improve preparedness for wildfire events and 


\section{extinction efficiency (W14, O3; W17, O3, Conclusions}

O6).

- Lack of adequate training of personnel means there is difficulty in obtaining more efficient prevention and suppressive actions. Researchers and managers occupy two distinct and largely unconnected worlds, which are separated by mutual distrust (W16, T9). It is advisable to integrate and combine scientific and technological know-how with new training (W16, O5, O13), thus enabling personnel to employ expert tactics and modern preventive fire use (suppression fires, prescribed burning) in forest management (W16, O6).

- Risk areas are irregularly distributed across the territory, and the control apparatus is not currently aligned with this distribution. It is necessary to focus actions on specific high-risk areas (W17, O3), which are identified using risk-maps.

\section{ST and SO strategies}

- Algeria has specific firefighting policies and laws. It seems necessary to update these policies and laws under the form of a modern and stringent discipline in regards to arson and negligent fire, including the creation of dedicated legislation for WUIs (S1, O2, O8) and an update of the Forest Cadastre and the new Forestry Code (S1, O9).

- The importance of the forest sector for local job and income creation is not well perceived as a priority within the current political agenda. This gap must be filled (S2, T10) as a subsidiary tool of PPDR (Projects of Rural Development).

- The important fire fighting apparatus and the impressive network of infrastructures must be integrated by a better interaction between researchers and managers (S3, T9) and in the scope of permanent training of personnel (S3, O5). Traditional knowledge in the use of fire must be exploited to develop and implement expert tactics and preventive fires, thereby improving extinction efficiency (S3, T3, O6).

- The ambitious reforestation program of 1245900 ha is a relevant strength because it demands an efficacious firefighting program, but it is not coherent for the state, due to the lack of management plans for state forests. All new afforestation areas must be endowed, from their project phase, with management plans that pay specific attention to fire prevention ( $\mathrm{S} 4, \mathrm{O} 4, \mathrm{O} 6)$. In such areas, forest management must receive high priority on the political agenda (S4, T10), which is inclusive of the need to increase employment and local income (S4, O1).

- PPDR are a powerful tool for local job creation (S5, O1), which in turn can be an efficacious means for facilitating a deeper involvement of local residents (S5, O11).
A qualitative SWOT analysis based on the literature review, personal knowledge and the opinions of a number $(\mathrm{N}=228)$ of wildfire experts using questionnaire surveys allowed to explore the national fire control apparatus in Algeria and identify its strengths and weakness. One of the more significant findings emerged from this study is that increasing suppression efforts alone will not solve the forest fire problem, especially in the future scenarios of higher fire risk, frequency and intensity and of increasing numbers of large fires in WUIs (Herrero 2009, Lampin-Maillet et al. 2010). Underpinning this study is the knowledge that fire exclusion-oriented policies need to be complemented with forest fire prevention management (Fernandes 2010, 2013), mainly in the form of fuel-reduction techniques and largescale fuel management. This study highlights the need to further focus on wildfire preventive actions and to make prevention a permanent activity. Our results are therefore coherent with the recommendations of the "Athens Declaration on Forest Fires" (MIO/ ECSDE 1987) in the fields of research, communication and information, and education and training.

There are challenges and difficulties ahead, not least because wildfires are a very visible and immediate threat. This means that it is often more socially and politically expedient to commit resources to suppression activities than to address the issues involved in longterm fire prevention measures and management (FAO 2011). In addition, preventive actions (mainly fuel-reduction techniques, including large-scale fuel management and fire prevention management of forests) are often less visible than suppression materials, such as firefighting tanker airplanes, 4WD vehicles and firefighting trucks, and therefore receive less political attention and are assigned fewer resources (FAO/JRC/CFS 2008).

As a result of this study, Algerian foresters are aware of the opportunity to shift from a mere control policy to a more preventionoriented one; they strongly call for a more pro-active approach on the part of the General Directorate of Forests. This viewpoint is in line with the opinions of foresters working in other countries. Forest fire prevention is actually considered to be one of the pillars of integrated, sustainable forest management (Montiel \& Galiana 2005, Silva et al. 2010a, 2010b, Moreira et al. 2011). Investments in suppression-oriented actions at the expense of prevention are considered a weakness in the SWOT analysis of wildfire legislation and policy for the Mediterranean region (FAO/JRC/CFS 2008). Foresters' participation in the survey permitted the identification of many obstacles to the implementation of a more efficacious control activity, sug- gesting reality-based strategic recommendations to overcome such obstacles. The results from our research are coherent with those obtained by the FireSmart project in EU countries (FIRESMART 2011) and with those observed in Europe in the frame of the European Integrated Project FIRE PARADOX (2006-2010), which provided recommendations for long-term policy measures able to encourage a shift in the current wildfire situation (Aguilar et al. 2009, Herrero et al. 2009). The lack of management in public and private forests, the view that fire prevention is judged to be more effective than extinction, the importance of training technical staff, the non-appropriate transfer of knowledge to forest fire prevention, and the importance of infrastructures are among the most important common issues, but are of course accompanied by specific differences.

Herein, we highlight the importance of the survey conducted among Algerian foresters. This is the first research paper for Algeria, and perhaps any MENA country, to have approached this sensitive subject. These foresters have an institutional monopoly on forest fire fighting and therefore refrain from publicly discussing their performance and opinions. Their collaborative participation in this survey is a cornerstone in the firefighting history of the country.

Most of the recommendations suggested, particularly those involving people from local communities, are fully applicable to other countries. The Community-Based Fire Management model (FAO 2011), whose strategy is grounded on the substantial involvement of local communities in preventing, controlling or using fires (for controlling weeds, reducing the impact of pests and diseases, generating income from non-timber forest products, creating forage and hunting, etc.), is an interesting and potentially useful approach for helping managers and decision makers in Algeria and other countries of North Africa and at MENA level to address wildfire issues. Significant improvements could be achieved by promoting more active participation by the public in firefighting operations; for instance, in establishing associations of properly trained volunteers, an option that is producing good results in several countries.

\section{Acknowledgments}

We are grateful to the Direction Générale des Forêts (DGF) of Algeria, whose collaboration permitted this research, and all experts (foresters) that accepted to participate. We thank the reviewers for their constructive comments, which helped us to improve the manuscript. We also thank Dr. Robert Stacey, PhD, Northumberland Fire and Rescue Service, UK, for improving the quality of this manuscript. 


\section{References}

Aguilar S, Galiana L, Lázaro A (2009). Analysis of wildfire risk management from a territorial policies perspective: strengths and weaknesses in the European framework. In: Proceedings of the " 3 rd International Symposium on Fire Economics, Planning, and Policy: Common Problems and Approaches" (González Cabán ed). Albany (California) November 2009. Gen. Tech. Rep. PSW-GTR-227, Pacific Southwest Research Station, USDA Forest Service, Albany, CA, USA, pp. 261-272. [online] URL: http://www.fs.fed us/psw/publications/documents/psw_gtr227en/ps w_gtr227_en.pdf

Bekdouche F, Sahnoune M, Krouchi F, Achour S, Guemati N, Derridj A (2011). The contribution of legumes to post-fire regeneration of Quercus suber and Pinus halepensis forests in North-eastern Algeria. La Terre et la Vie - Revue d'écologie 66 (1): 43-54. [online] URL: http://www.researchgate.net/publication/261361405

Blinn CR, Jakes PJ, Sakai M (2007). Forest landowner cooperatives in the United States: a local focus for engaging landowners. Journal of Forestry 105 (5): 245-250. [online] URL: http:// www.nnfp.org/CCFE/Docs/PDF/ForestLandown erCooperativesBlinnEtA12007.pdf

Boström C, Sebastián A, Hernando Lara C, Planelles R, Buffoni A, Alves R, Jappiot M and San Miguel Ayanz J (2013). Forest and land management options to prevent unwanted forest fires. In: "Trees, Forested Landscapes and Grazing Animals. A European Perspective on Woodlands and Grazed Treescapes" (Rotheram JD ed). Routledge, New York, USA, pp. 180-188.

Colaço MC (2005). Prevenção de Incêndios Florestais: Um estudo sobre a formação dos técnicos florestais [Forest Fires prevention: a study on the training of forestry technicians]. Trabalho de Investigação tutelado do doutoramento inter-universitário em Educação Ambiental, Universidade de Santiago de Compostela, Spain, pp. 111. [in Spanish]

Colaço MC, Rego FC, Meira P (2006). Forest fire prevention: a study about the forest technician's training. In: Proceedings of the " $5^{\text {th }}$ International Conference on Forest Fire Research" (Viegas DX ed). Figueira da Foz (Portugal), 27-30 November 2006, pp. 13. [CD Rom]

Colaço MC, Castro Rego F, Meira P, Santos T (2005). What are the opinions of foresters in Portugal regarding fire? Results of a questionnaire. In: Proceedings of the " 2 nd International Conference on Prevention Strategies of Fire in Southern Europe”. Barcelona (Spain), 9-11 May 2005. CTFC/COSE/USSE, Barcelona, Spain, pp. 5 [online] URL: http://www.isa.utl.pt/ceabn/uploa ds/docs/projectos/opinionsforestersportugal.pdf

Colombo SJ (2006). How OMNR staff perceive risks related to climate change and forests. Research Note 2, Ontario Forest Research Institute, Ontario Ministry of Natural Resources, Sault Ste. Marie, ON, Canada, pp. 8. [online] URL: http:// www.academia.edu/4246065/

De Ribbe C (1869). Des incendies de forêts dans la région des Maures et de l'Esterel (Provence).
Leurs causes. Leur histoire. Moyens d'y remédier [Forest fires in the Maures and Esterel area (Provence). Their causes, their history. ways to address them] ( $2^{\text {nd }}$ edn). Librairie Agricole, Société Forestière des Maures, Paris, France, pp. 140. [in French] [online] URL: http://archive. org/details/desincendiesdef00ribbgoog

EFIMED (2012). The fight against forest fires: an inconvenient truth? EFIMED network news, Mediterranean Regional Office, European Forest Institute, Barcelona, Spain, pp. 1. [online] URL: http://news.efi.int/newsletter/view/efimed-news letter-august-2012/1044

European Commission (2013). Forest fires in Europe, Middle East and North Africa 2012. Publications Office of the European Union, Luxembourg, pp. 109. [online] URL: http://forest.jrc.ec. europa.eu/media/cms page media/9/FireReport 2012_Final_2pdf_2.pdf

FAO/JRC/CFS (2008). Workshop on wildfires in the Mediterranean region: prevention and regional cooperation. Sabaudia (Italy) 13-15 May 2008. FAO, Rome, Italy, pp. 22. [online] URL: ftp://ttp.fao.org/docrep/fao/010/k2891e/k28 91e00.pdf

FAO (2011). Community-based fire management: a review. FAO Forestry paper 166. FAO, Rome, Italy, pp. 81. [online] URL: http://www.fao.org/ docrep/015/i2495e/i2495e.pdf

FAO (2013). State of Mediterranean Forests 2013. FAO, Rome, Italy, pp. 173. [online] URL: http:// www.fao.org/docrep/017/i3226e/i3226e.pdf

Fernandes PM (2010). Creating fire-smart forests and landscapes. Forêt méditerranéenne 31 (4): 417-422. [online] URL: http://www.researchgate.net/publication/215705635

Fernandes PM (2013). Fire-smart management of forest landscapes in the Mediterranean basin under global change. Landscape and Urban Planning 110: 175-182. - doi: 10.1016/j.landurbplan. 2012.10.014

FIRESMART (2011). Forest and land management options to prevent unwanted forest fires. Technical report 1 (WP1): compilation and preliminary analysis of actual knowledge/practice in forest fire prevention. Web site, pp. 123. [online] URL: http://www.firesmart-project.eu/docs/pro jectdocs/R1_Prevention_knowledge_and_practi ces.pdf

Gerasimov Y, Karjalainen T (2008). Development program for improving wood procurement in Northwest Russia based on SWOT analysis. Baltic Forestry 14 (1): 87-92. [online] URL: http://www.balticforestry.mi.lt/bf/PDF_Articles/ 2008-14[1]/BF14(1

Ghazinoory S, Abdi M, Azadegan-Mehr M (2011). SWOT methodology: a state-of-the-art review for the past, a framework for the future. Journal of Business Economics and Management 12 (1): 24-48. - doi: 10.3846/16111699.2011. 555358

Ghiculescu D, Marinescu N, Ghiculescu D, Nanu S (2011). Computer aided SWOT analysis applied to SMES using concentrated energies technologies. In: Proceedings of the "International Conference on Manufacturing Science and Edu- cation - MSE 2011”. Lucian Blaga University of Sibiu, LBUS (Romania) 2-5 jun 2011. Sibiu, Romania, pp. 213-216. [online] URL: http://www doctorate-posdru.ulbsibiu.ro/media/phd/file 31c d_conf_proc_full_article_000686.pdf Giannakopoulos C, Le Sager P, Bindi M, Moriondo M, Kostopoulou E, Goodess CM (2009). Climatic changes and associated impacts in the Mediterranean resulting from a $2{ }^{\circ} \mathrm{C}$ global warming. Global Planetary Change: 209224. - doi: 10.1016/j.gloplacha.2009.06.001

Guettouche MS, Derias A, Boutiba M, Bounif M, Guendouz M, Boudella A (2011). A fire risk modelling and spatialization by GIS. Journal of Geographic Information System 3 (3): 254-265. doi: 10.4236/jgis.2011.33022

Haddouche I, Benhanifia K, Gacemi M (2011). Analyse spatiale de la régénération forestière post-incendie de la forêt de Fergoug à Mascara, Algérie [Spatial analysis of post-fire regeneration in the forest of Fergoug in Mascara, Algeria]. Bois et Forêts des Tropiques 65 (307): 23-31. [in French] [online] URL: http://bft.revuesonline. com/article.jsp?articleId $=16128$

Herrero G (2009). Assessment of the growing importance of wildland-urban interfaces in fire risk management: wui regional patterns in Spain. In: Proceedings of the " 3 rd International Symposium on Fire Economics, Planning, and Policy: Common Problems and Approaches" (González Cabán A ed). Albany, California, November 2009. Gen. Tech. Rep. PSW-GTR-227, Pacific Southwest Research Station, USDA Forest Service, Albany, CA, USA, pp. 238-248. [online] URL: http://www.fs.fed.us/psw/publications/do cuments/psw_gtr227en/psw_gtr227 en.pdf

Herrero G, Lázaro A, Montiel C (2009). A comparative assessment of the European forest policies and their influence in wildfire management. In: Proceedings of the " $3{ }^{\text {rd }}$ International Symposium on Fire Economics, Planning, and Policy: Common Problems and Approaches" (González Cabán A ed). Albany (CA, USA), Nov 2009. Gen. Tech. Rep. PSW-GTR-227, Pacific Southwest Research Station, USDA Forest Service, Albany, CA, USA, pp. 273-282. [online] URL: http://www.fs.fed.us/psw/publications/document s/psw_gtr227en/psw_gtr227_en.pdf

Khader M, Benabdeli K, Mederbal K, Fekir Y, Gueddim R, Mekkous B (2009). Etude du risque incendie à l'aide de la géomatique: cas de la forêt de Nesmoth (Algérie) [Study of fire risk by geomatics: the case of the Nesmoth forest (Algeria)]. Mediterranea Serie de Estudios Biológicos, Época II 20: 10-38. [in French] [online] URL: http://rua.ua.es/dspace/bitstream/10045/28578/1/ Mediterranea_20.pdf

Lampin-Maillet C, Jappiot M, Long M, Bouillon C, Morge D, Ferrier JP (2010). Mapping wildland-urban interfaces at large scales integrating housing density and vegetation aggregation for fire prevention in the South of France. Journal of Environmental Management 91: 732-741. - doi: 10.1016/j.jenvman.2009.10.001

Likert R (1932). A technique for the measurement of attitudes. Archives of Psychology 140: 1-55. 
[online] URL: http://www.voteview.com/Likert 1932.pdf

Lovreglio R, Meddour-Sahar O, Leone V (2014). Goat grazing as a wildfire prevention tool: a basic review. iForest 7: 260-268. - doi: 10.3832/ ifor1112-007

Lu W (2010). Improved SWOT approach for conducting strategic planning in the construction industry. Journal of Construction Engineering and Management 136 (12): 1317-1328. - doi: 10.106 1/(ASCE)CO.1943-7862.0000240

Madoui A, Gehu JM, Alatou D (2006). L'effet du feu sur la composition des pinèdes de Pinus halepensis Mill. dans le Nord de la forêt de BouTaleb, Algérie [Fire effects on the composition of Pinus halepensis communities in the North of Bou-Taleb forest, Algeria]. Ecologia Mediterranea 32: 5-13. [in French] [online] URL: http:// www.univ-avignon.fr/uploads/media/Ecologia mediterranea_2006-32.pdf

Marino E, Hernando C, Planelles R, Madrigal J, Guijarro M, Sebastián A (2014). Forest fuel management for wildfire prevention in Spain: a quantitative SWOT analysis. International Journal of Wildland Fire 23 (3): 373-384. - doi: 10.1071/WF12203

Meddour-Sahar O (2014). Les feux de forêt en Algérie: analyse du risque, étude des causes, évaluation du dispositif de défense et des politiques de gestion [Forest fires in Algeria: risk analysis, study of the causes, evaluation of defence apparatus and management policies]. Thèse de Doctorat en Sciences Agronomiques, Université Mouloud Mammeri, Tizi Ouzou, Algeria, pp. 256. [in French] [online] URL: http://www.um mto.dz/IMG/pdf/Meddour-Sahar_Ouahiba.pdf Meddour-Sahar O, Lovreglio R, Meddour R, Leone V, Derridj A (2013a). Fire and people in three rural communities in Kabylia (Algeria): results of a survey. Open Journal of Forestry 3: 3040. - doi: 10.4236/ojf.2013.31006

Meddour-Sahar O, González Cabán A, Meddour R, Derridj A (2013b). Wildfire management policies in Algeria: present and future needs, public policies. In: Proceedings of the " $4^{\text {th }}$ International Symposium on Fire Economics, Planning and Policy: Climate Change and Wildfires" (González-Cabán A ed). Albany (CA) Nov 2012. Gen. Tech. Rep. PSW-GTR-245, Pacific Southwest Research Station, USDA Forest Service, Albany, CA, USA, pp. 245-382. [online] URL: http://www.fs.fed.us/psw/publications/documen ts/psw_gtr245/psw_gtr245.pdf

Meddour-Sahar O, Meddour R, Leone V, Lovreglio R, Derridj A (2013c). Analysis of wildfires causes and their motivations in North Algeria: the Delphi method. iForest 6: 247-254. - doi: 10.3832/ifor0098-006

Megrerouche R (2006). Sensibilité de la végétation forestière aux incendies: cas de la forêt domaniale de Chettabah - Ain Smara - Constantine [Forest vegetation fire- sensitivity : the case of the forest of Chettabah - Ain Smara - Constantine]. Mémoire de Magistère en Ecologie et Environnement, Université de Constantine, Constantine, Algeria, pp. 106. [in French] [online]
URL: http://bu.umc.edu.dz/theses/biologie/MEG 4802.pdf

MIO/ECSDE (1987). The Athens declaration on forest fires (2 April 1987). MIO-ECSDE, Mediterranean Information Office for Enviroment, Culture and Sustainable Development, Athens, Greece, pp. 2. [online] URL: http:// m.mio-ecsde.org/old/Publications/Other/agreed/2_agr.htm Mitroff I, Turoff M (1975). Philosophical and methodological foundations of Delphi. In: "The Delphi Method: Techniques and Applications". (Linstone $\mathrm{H}$, Turoff $\mathrm{M}$ eds). Addison-Wesley, Reading, MA, USA, pp. 17-35. [online] URL: http://is.njit.edu/pubs/delphibook/delphibook.pdf Mogas J, Riera P (2001). The economic value of risk reduction of forest fires in Spain. In: Proceedings of the "IUFRO International Symposium on the economics of natural hazards in forestry". Solsona (Spain) 7-10 Jun 2001, pp. 8. [online] URL: http://pagines.uab.cat/pere.riera/ sites/pagines.uab.cat.pere.riera/files/ponencia08. pdf

Mohamad MI, Nekooie MA, Taherkhani R, Saleh AL, Mansur SA (2012). Exploring the potential of using industrialized building system for floating urbanization by SWOT analysis. Journal of Applied Sciences 12: 486-491. - doi: 10.3923/ jas.2012.486.491

Molina D, Castellnou M, García-Marco D, Salgueiro A (2010). Improving fire management success through fire behavior specialists. In: "Towards Integrated Fire Management-Outcomes of the European Project Fire Paradox". (Silva JS, Rego F, Fernandes P, Rigolot E eds). Research Report 23, European Forest Institute, Joensuu, Finland, pp. 105-119. [online] URL: http://www.ucm.es/data/cont/docs/530-2013-1015-efi rr23.pdf

Montiel C, Galiana L (2005). Forest policy and land planning policy in Spain: a regional approach. Forest Policy and Economics 7 (2): 131142. - doi: 10.1016/S1389-9341(03)00026-1

Montiel C, Herrero G (2010). An overview of policies and practices related to fire ignitions at the European Union level. In: "Towards Integrated Fire Management-Outcomes of the European Project Fire Paradox". (Silva JS, Rego F, Fernandes P, Rigolot E eds). European Forest Institute, Joensuu, Finland, Research Report 23, pp. 35-46. [online] URL: http://www.ucm.es/ data/cont/docs/530-2013-10-15-efi rr23.pdf

Moreira F, Viedma O, Arianoutsou M, Curt T, Koutsias N, Rigolot E, Barbati A, Corona P, Vaz P, Xanthopoulos G, Mouillot F, Bilgili E (2011). Landscape-wildfire interactions in southern Europe: implications for landscape management. Journal of Environmental Management 92: 2389-2402. - doi: 10.1016/j.jenvman.2011.06. 028

Ohadi S, Dorbeiki M, Bahmanpour H (2013). Environmental strategies of nature tourism in biosphere reserves: a case study of Miankaleh, Iran. European Journal of Experimental Biology 3 (5): 176-182. [online] URL: http://pelagiaresearchlibrary.com/european-journal-of-experimental-biology/vol3-iss5/EJEB-2013-3-5-176-182.pdf
Ouelmouhoub S, Benhouhou S (2007). Evolution floristique des subéraies incendiées dans la région d'El Kala (Nord-est algérien) [Post fire floristic evolution of cork-oak forests in the El Kala region (northeastern Algeria)]. Ecologia Mediterranea 33: 85-94. [in French] [online] URL: http://dialnet.unirioja.es/servlet/articulo?co digo $=4654393$

Plana E (2010). Integration of fire risk in land use planning and forest management tools in Catalonia (NW Spain), In: Report of the "Forest Europe 2010. Assessment of Forest Fire Risks and Innovative Strategies for Fire Prevention workshop". Rhodes (Greece) 4-6 May 2010, pp. 48. [online] URL: http://www.foresteurope.org/docs/other meetings/2010/forest_risk/14_Plana.pdf

Raftoyannis Y, Nocentini S, Marchi E, Calama Sainz R, Garcia Guemes C, Pilas I, Peric S, Amaral Paulo J, Moreira-Marcelino Ana C, Costa-Ferreira M, Kakouris E, Lindner M (2014). Perceptions of forest experts on climate change and fire management in European Mediterranean forests. iForest 7: 33-41. - doi: 10.3832/ifor0817-006

Rauch P (2007). SWOT analyses and SWOT strategy formulation for forest owner cooperation in Austria. European Journal of Forest Research 126: 413-420. - doi: 10.1007/S10342-006-01622

Sebastián-López A, Carmen Hernando L, Planelles R, Buffoni A, Boström C, Alves R, Jappiot M, San Miguel Ayanz J (2011). EU-FIRESMART: Forest and land management options to prevent unwanted forest fires. In: Proceedings of the "Wildfire 2011. The $5^{\text {th }}$ International Wildland Fire Conference". Sun City (South Africa) 9-13 May 2011, pp. 1-11. [online] URL: http:// www.wildfire2011.org/material/papers/Ana_Sebastian_Lopez.pdf

Silva JS, Rego FC, Fernandes P, Rigolot E (2010a). Introducing the Fire Paradox. In: "Towards Integrated Fire Management-Outcomes of the European Project Fire Paradox". (Silva JS, Rego F, Fernandes P, Rigolot E eds). Research Report 23, European Forest Institute, Joensuu, Finland, pp. 2-6. [online] URL: http://www. ucm.es/data/cont/docs/530-2013-10-15-efi rr23. pdf

Silva JS, Rego FC, Fernandes P, Rigolot E (2010b). Solving the Fire Paradox. Regulating the wildfire problems by the wise use of fire. In: "Towards Integrated Fire Management-Outcomes of the European Project Fire Paradox". (Silva JS, Rego F, Fernandes P, Rigolot E eds). Research Report 23, European Forest Institute, Joensuu, Finland, pp. 219-228. [online] URL: http://www.ucm.es/data/cont/docs/530-2013-1015-efi_rr23.pdf

Slimani S, Touchan R, Derridj A, Kherchouche D, Gutiérrez E (2014). Fire history of Atlas cedar (Cedrus atlantica Manetti) in Mount Chélia, northern Algeria. Journal of Arid Environments 104: 116-123. - doi: 10.1016/j.jaridenv.2014.02. 008

Suh J, Emtage NF (2005). Identification of strengths, weaknesses, opportunities and threats 
of the community-based forest management program. Annals of Tropical Research 27 (1): 55 66. [online] URL: http://espace.library.uq.edu. au/eserv.php?pid=UQ:8243

Taylor D (1997). Seeing the forests for more than the trees. Environmental Health Perspectives 105 (11): 1186-1191. [online] URL: http://www ncbi.nlm.nih.gov/pmc/articles/PMC1470324/pdf /envhper00324-0034-color.pdf

Torres-Manso F, Fernandes P, Pinto R, Botelho H, Monzon A (2014). Regional livestock grazing, human demography and fire incidence in the Portuguese landscape. Forest Systems 23 (1): 15 21. - doi: $10.5424 /$ fs/2014231-02758

Vélez R (2000). La defensa contra incendios forestales. Fundamentos y experiencias [Wildfires defence: fundamentals and experiences]. McGraw-Hill/Interamericana de España S.A.U., Madrid, Spain, pp. 1281. [in Spanish]

Weihrich H (1982). The TOWS matrix: a tool for situational analysis. Long Range Planning 15 (2): 54-66. - doi: 10.1016/0024-6301(82)901200

Williamson TB, Price DT, Beverly J, Bothwell PM, Parkins J, Patriquin N, Pearce CV, Stedman RC, Volney WJA (2005). A framework for assessing vulnerability of forest-based communities to climate change. Information report NORX-414, Natural Resources Canada, Canadian Forest Service Northern Forestry Centre, Edmonton, Alberta, Canada, pp. 51. [online] URL: http://cfs.nrcan.gc.ca/bookstore_pdfs/27507.pdf Xavier A, De Belém Martins M (2010). The agroforestry farms' socioeconomic characterization for a forest fire prevention and management model. In: Proceedings of the " 3 rd WSEAS International Conference on Climate Changes, Global Warming, Biological Problems" (Panagopoulos T ed). University of Algarve, Faro (Portugal) 3-5 nov 2010. WSEAS Press, Faro, Portugal, pp. 57-
63. [online] URL: http://www.wseas.us/books/ 2010/Faro/NAGB.pdf

Zarraga Moreno JL (1988). Los incendios forestales y las actitudes de la poblacion de las comarcas afectadas [Wildfires and the attitudes of the populations of the affected regions]. Servicio de Estudios e Informes del IARA, Sevilla, Spain, pp. 99. [in Spanish]

\section{Supplementary Material}

Appendix 1 - Wildfires in Algeria: problems and challenges. (1) Management of wildfires (Mean and Std. Dev.); (2) Prevention of forest fires; (3) Rating of techniques and activities aimed at the prevention of wildfires (average \pm Std. Dev.); (4) Possible conflicts.

Link: Meddour_1279@supp1001.pdf 